\title{
Is Corporate Disclosure Behavior Really Sticky?
}

Jing-Wen Yang, California State University, East Bay, USA

\begin{abstract}
This study examines whether corporate disclosure behavior is "sticky" and if so, why. From the Company Issued Guidance database created by Thompson First Call, 1,085 firm-years in which a firm skips a year of earnings forecast are identified. Based on a logit analysis, three potential reasons for that skip are explored: 1) the company missed its earnings target in the prior year, 2) they experienced more earnings volatility than expected, and 3) they received incoming bad news. The results show that a firm is more likely to skip if it missed its earnings target by a large margin in the prior year. The results also suggest that this occurs in cases where a firm experiences higher earnings volatility. Incoming bad news is not a factor.
\end{abstract}

Keywords: Disclosure Behavior; Earnings Forecast; Earnings Targets; Earnings Volatility

\section{INTRODUCTION}

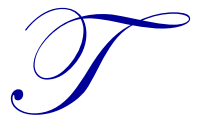

he behavior surrounding management earnings guidance has long been a topic of interest to academic researchers. While most studies focus on examining the determinants and the consequences of management earnings forecast behavior (e.g., Waymire, 1985; Pownall, et. al., 1993; Baginski \& Hassell, 1997; Coller \& Yohn, 1997), little is known about time-series changes in management earnings forecast behavior.

The purpose of this paper is to fill this void by addressing the following two questions: 1) does a firm consistently project its earnings number from period to period, and 2) if not, what causes the inconsistency?

Based upon the Company Issued Guidance database created by Thomson First Call, the years in which a firm skips its annual earnings forecast are identified; more specifically, any gaps in year(s) in which a firm suddenly drops an earnings forecast. The sample years investigated lie between 1993 and 2007. Limiting to those firms where the fiscal year ends in December, 1,168 firm-years in which management earnings forecast are skipped were identified. To make sure these firm-years actually skipped their annual earnings forecast, the newswires and the final number of skipped firm-years were checked, thereby identifying a final number of 1,085. Among these, about forty percent of skipped forecasts occurred in 1999, 2000, and 2002.

The fact that firms can skip a year of earnings forecast casts doubt on an argument posited by prior studies. Previous studies suggest that firms' disclosure policies tend to be "sticky" (Bushee, et. al., 2003; Skinner, 2003; Graham, et. al., 2004; Field, et. al., 2005). They argue that some firms have a long-standing policy to provide frequent earnings guidance while other firms stay with a tradition of non-disclosure. The findings in this study imply that disclosure policies could be less "sticky" than researchers commonly believe.

Exploring potential reasons that cause a firm to skip a year of earnings forecast results in hypotheses that firms are more likely to engage in this practice if 1) they missed earnings targets in a previous year, 2) they experienced more volatile earnings, or 3) they received incoming bad news. To test these hypotheses, firm-years with complete financial data were examined and the following samples were identified: 690 skipped firm-years and 3,197 regular forecasting control firm-years. Based on a logit analysis, the findings indicate that firms that have missed earnings targets in a previous year are more likely to skip. The results also show that firms with more 
volatile earnings in the previous five years are more inclined to do so. The results, however, do not suggest that firms with incoming bad news are more likely to skip.

By providing a time-series analysis of management earnings forecast behavior, this research casts doubt on a common belief that disclosure policy tends to be sticky.

This study complements two related studies by Houston, et. al. (2010) and Chen, et. al. (2011). Both studies investigate time-series change in management earnings forecast behavior. However, their focus is on firms that stop giving quarterly earnings guidance, while the focal point here is on firms that skip a year of forecast. Sample firms within this study actually exclude firms that permanently stop their forecasts.

\section{STICKY CORPORATE DISCLOSURE POLICY}

To explore whether a firm would actually skip a year of earnings forecast, the Company Issued Guidance (CIG) database generated by Thomson First Call was used as a test bed. The initial sample is limited to all forecasts about annual earnings per share (EPS) issued by management between calendar years 1993 and 2007. The sample firms are restricted to those with fiscal year ending December 31 to ease data collection. For a given firm, the year(s) in which it skips making a forecast number is/are identified. For example, if a firm has earnings forecast for years 1996 and 1997 and then makes its next earnings forecast for year 1999 or after, 1998 is considered a skip year. The year in which a firm completely stops its earnings forecast is not included.

Among 937 firms, 1,168 firm-years in which a firm skips its earnings forecast were isolated. Since Anilowski et. al. (2007) indicate that the CIG database is incomplete, Factiva news database was searched to make sure that initially identified cases actually skipped annual earnings forecast. For each skipped year, all news hits were browsed under the keyword phrase "earnings projection." The time period of the Factiva examination ranges from the time a firm last made its annual earnings forecast to four months after the fiscal year end of a skipped year. The publications searched include Business Wire, PR Newswire, Associated Press Newswires, and Reuters Significant Developments. Of the CIG-identified skipped firm-years, 83 actually had annual earnings forecasts. The final number of skipped firm-years is 1,085 among 885 firms.

Table 1: Characteristics of Skipped Management Earnings Forecasts and Skipped Firms

Panel A: Descriptive Statistics Of Firm Size And Income Before Extraordinary Items For The 1,086 Firm-Years That A Firm Skips An Earnings Forecast (Versus All Other Firm-Years With Fiscal year-End In December But Excluding Skipped FirmYears)

\begin{tabular}{|l|c|c|c|c|c|}
\hline & Mean & Std. Dev. & Q1 & Median & Q3 \\
\hline Size & $1,396,425$ & $12,498,331$ & 1,555 & 9,345 & 65,167 \\
\hline Skipped firm-years & $1,236,777$ & $18,315,917$ & 164 & 1,449 & 16,949 \\
\hline Other firm-years & & & -1.13 & 18.31 & 90.71 \\
\hline Income before extraordinary items & 153.79 & 870.49 & -2.62 & 4.96 & 39.14 \\
\hline Skipped firm-years & 121.25 & 913.55 & &
\end{tabular}

Panel B: Relative Percentage Of Bad News* Firm-Years And Loss** Firm-Years

\begin{tabular}{|l|c|c|}
\hline & Firm-Years Skipped & Other Firm-Years \\
\hline Bad news & $41.01 \%$ & $36.04 \%$ \\
\hline Loss & $26.08 \%$ & $32.18 \%$ \\
\hline
\end{tabular}

* A firm-year is classified as a bad news firm-year when the current year's income, before extraordinary items, is less than last year's.

** A firm-year is viewed as a loss firm-year if the income before extraordinary items is less than zero. 
Panel C: Frequency Of Skipped Management Earnings Forecasts By Year

\begin{tabular}{|c|c|c|}
\hline Year & Number Of Skipped Firm-Years & $\%$ \\
\hline 1994 & 1 & 0.09 \\
\hline 1995 & 12 & 1.11 \\
\hline 1996 & 84 & 7.74 \\
\hline 1997 & 85 & 7.83 \\
\hline 1998 & 101 & 9.31 \\
\hline 1999 & 135 & 12.44 \\
\hline 2000 & 174 & 16.04 \\
\hline 2001 & 89 & 8.20 \\
\hline 2002 & 128 & 11.80 \\
\hline 2003 & 103 & 9.49 \\
\hline 2004 & 54 & 4.98 \\
\hline 2005 & 72 & 6.64 \\
\hline 2006 & 34 & 3.13 \\
\hline 2007 & 13 & 1.20 \\
\hline Total & 1085 & 100.00 \\
\hline
\end{tabular}

\section{Panel D: Industry Composition}

\begin{tabular}{|c|c|c|}
\hline Industry Groups* & $\%$ Of Skipped Firm-Years & $\%$ Of Other Firm-Years \\
\hline aero & 0.46 & 0.35 \\
\hline agric & 0.55 & 0.21 \\
\hline autos & 2.49 & 1.12 \\
\hline banks & 7.38 & 14.23 \\
\hline beer & 0.46 & 0.31 \\
\hline bldmt & 1.75 & 1.49 \\
\hline books & 0.92 & 0.74 \\
\hline boxes & 0.46 & 0.25 \\
\hline bussv & 16.97 & 10.49 \\
\hline chems & 2.21 & 1.64 \\
\hline chips & 4.52 & 4.35 \\
\hline clths & 1.75 & 0.82 \\
\hline cnstr & 1.11 & 0.99 \\
\hline coal & 0.37 & 0.18 \\
\hline comps & 3.41 & 3.25 \\
\hline drugs & 5.26 & 6.08 \\
\hline elceq & 1.29 & 0.66 \\
\hline enrgy & 2.49 & 4.52 \\
\hline fabpr & 0.37 & 0.28 \\
\hline fin & 1.85 & 6.24 \\
\hline food & 0.65 & 0.84 \\
\hline fun & 0.83 & 1.29 \\
\hline gold & 0.18 & 0.86 \\
\hline gov & 0.18 & 0.16 \\
\hline hlth & 2.40 & 1.71 \\
\hline hshld & 2.31 & 1.17 \\
\hline insur & 4.61 & 4.46 \\
\hline labeq & 1.57 & 1.56 \\
\hline mach & 3.60 & 2.43 \\
\hline meals & 1.75 & 1.63 \\
\hline medeq & 3.41 & 2.57 \\
\hline mines & 0.37 & 0.63 \\
\hline misc & 0.46 & 0.89 \\
\hline paper & 1.48 & 1.13 \\
\hline persv & 1.20 & 0.68 \\
\hline rlest & 0.37 & 0.89 \\
\hline
\end{tabular}




\begin{tabular}{|l|c|c|}
\hline rtail & 2.12 & 1.99 \\
\hline rubbr & 0.83 & 0.72 \\
\hline ships & 0.46 & 0.14 \\
\hline smoke & 0.09 & 0.15 \\
\hline soda & 0.28 & 0.24 \\
\hline steel & 1.29 & 1.33 \\
\hline telcm & 1.85 & 4.16 \\
\hline toys & 1.11 & 0.77 \\
\hline trans & 3.41 & 2.74 \\
\hline txtls & 0.46 & 0.34 \\
\hline util & 4.15 & 3.72 \\
\hline whlsl & 2.49 & 2.60 \\
\hline Total & 100.00 & 100.00 \\
\hline
\end{tabular}

* Firm-years are classified into different industry groups according to the industry classification proposed by Fama and French (1997).

Panel E: Percentage Of Firms Which Repeatedly Skip A Year Of Earnings Forecast

\begin{tabular}{|c|c|c|}
\hline Number Of Earnings Forecast Skipped & Number Of Firms & Percentage \\
\hline 4 & 1 & 0.11 \\
\hline 3 & 23 & 2.60 \\
\hline 2 & 151 & 17.06 \\
\hline 1 & 710 & 80.23 \\
\hline Total & 885 & 100.00 \\
\hline
\end{tabular}

In Table 1, Panel A indicates that the mean (median) size, measured as the market value of equity at the end of each year, of the skipped firm-years is $\$ 1,396,425(\$ 9,345)$, while the mean (median) size of other firm-years is $\$ 1,236,777$ (\$1,449). In other words, the size of firms that skip years of earnings forecasts is, on average, larger. This could be because a larger firm tends to make earnings forecasts in the first place. It could also imply that a large firm is more likely to skip a year of forecast.

In Table 1, Panel B shows that forty-one percent of the skipped firm-years occur in the same years as those in which a firm experiences bad news, while only thirty-six percent of other firm-years experience bad news. This could indicate that a firm skips a year of forecast because its current performance is not as good as in the previous year. On the other hand, skipping a year of forecast is not necessarily related to reporting a loss in that year. Only $26.08 \%$ of skipped firm-years are coincident with reports of losses in the same year, which is lower than the percentage $(32.18 \%)$ of other firm-years where there were reported losses.

In Table 1, Panels C and D show the frequency of skipped incidences by year and industry composition (Fama \& French, 1997). About forty percent of the incidences occurred in 1999, 2000, and 2002. Furthermore, the firms that skip forecast years are mostly in the prepackaged software service industry, the banking industry, and the pharmaceutical industry (SIC codes $=7372,6020$ and 2834, respectively. They are included in the business services (bussv), banking (banks), and drugs industry (drugs) categories, respectively.

Another investigation was undertaken to determine whether incidences where firms skip forecast years occur around the same time as turnovers of chief executive officers (CEO), chief financial officers (CFO), or auditors. It was discovered that $27.28 \%$ (296 out of 1,085) of skipped firm-years occurred in the same period when CEOs or CFOs turned over (not tabulated). Among these 296 firm-years, $37.16 \%$ of the turnover resulted from the resignation of a CEO or CFO. Furthermore, for 10.32\% (112 out of 1,085) of skipped firm-years, a firm's change in its auditor occurred in the same year as or in the prior year to the skipped firm-year.

Prior studies believe that a firm is sticky in relation to its disclosure policy. In other words, if a firm holds a conference call or provides an earnings forecast in a given year, it is a common belief that it will do so consistently over time. The finding that a firm will actually skip a year of earnings guidance casts doubt on this common belief. Although a firm may have a long-standing corporate disclosure policy, the choice of whether to make voluntary disclosure could still change over a series of years. In the next section, several reasons that might cause a firm to skip a year of forecast are proposed. 


\section{HYPOTHESES DEVELOPMENT}

The concern that a firm might miss its earnings target for a second or subsequent year might trigger the firm to skip a year of forecast. A recent survey study indicates that managers believe that missing an earnings benchmark could cause a stock price to plummet (Graham, et. al., 2005). Empirical evidence also supports these managers' beliefs. For example, Skinner and Sloan (2002) find that growth firms that miss their earnings target (e.g., analysts' forecasts) exhibit disproportionately large stock price declines. In addition, Bartov, et. al. (2002) show that firms that fail to meet analysts' earnings expectations experience a lower abnormal return than firms that meet these expectations. This concern about dragging down the stock price because of a missed earnings target could result in the firm deciding to skip a year of forecast.

Managers might also be worried about their external reputation from the firm's missing its earnings target and this could cause them to skip a year of forecast. Graham et. al. (2005) point out this concern on the part of managers. If managers fail to meet earnings benchmarks in a given year, they may choose to keep silent for the next year in order not to affect their reputation and careers in a negative way. From the discussion above, the following hypothesis (in an alternative form) is suggested:

H1: Firms which miss earnings targets are more likely to skip a year of earnings forecast.

Early theoretical work (e.g., Grossman, 1981) suggested that firms would practice a full disclosure policy because it would be assumed that a firm that withheld information would do so as a result of bad news, resulting in full disclosure equilibrium. Despite this argument, subsequent disclosure models proposed by Dye (1985) and Jung and Kwon (1988) argued that partial disclosure equilibrium could exist because of the information uncertainty in the environment surrounding the time a firm made its disclosure. Their argument is that while information uncertainty exists, investors are unsure whether the manager has certain information. This, in turn, allows managers to successfully suppress information they possess. In other words, the higher the uncertainty about information, the more likely a firm can successfully withhold information without unraveling the nature of the withheld news.

A firm could choose to withhold a year of earnings forecast due to information uncertainty about earnings. Such information uncertainty about earnings could result from the volatility of earnings in the prior year. The survey study by Graham et. al. (2005) points out a widely held managerial belief that earnings volatility reduces earnings predictability. Therefore, if a firm's earnings number becomes too volatile to be predicted reasonably, the manager could decide to keep silent for that year. The hypothesis (in alternative form) is stated as follows:

H2: Firms with more volatile earnings are more likely to skip a year of earnings forecast.

In addition to earnings volatility, Verrecchia (1983) proposed two reasons why a firm withholds information: 1) A firm might experience good news, but the proprietary cost of disclosing it might be greater than the benefit or 2) a firm experiences bad news. In line with this view, empirical studies generally find a positive relationship between firm performance and disclosure (e.g., Land \& Lundholm, 1993; Miller, 2002).

If a firm expects a poor earnings number in the current year compared to the preceding year, it might not be motivated to release earnings guidance with the hope that earnings performance could revert to last year's level before it is finalized. In other words, giving out any precise and optimistic earnings guidance could mislead the market if the final earnings result is expected to be particularly bad. Thus, a firm could be inclined to keep silent in such a circumstance. The following directional prediction is proposed (in alternative form):

H3: Firms with incoming bad news are more likely to skip a year of earnings forecast.

In summary, firms with a record of missing earnings targets, more volatile earnings, and/or incoming bad news are inclined to miss a year of earnings forecast. The procedure for selecting sample firms and control firms is described in the next section. 


\section{METHODOLOGY, SAMPLE SELECTION, AND DATA COLLECTION}

To test potential reason(s) that could cause a firm to skip a year of earnings forecast, logit analysis was used. The CIG database was chosen to identify a group of control firm-years. With the sample period ranging from years 1993 to 2007, if a firm with a December fiscal year-end actually issued annual earnings forecast in a year, that year is included as a control firm-year. The number of regular forecasting firm-years identified was 11,948.

The logit model used in the test is as follows:

$$
\operatorname{Pr}(S K I P=1)=F\left(\beta_{0}+\beta_{1} M I S S+\beta_{2} V O L A T I L E+\beta_{3} B A D+\beta_{4} L S I Z E+\varepsilon\right)
$$

The dependent variable SKIP is 1 if a firm actually skips a year of forecast. The SKIP is 0 if a firm issues a forecast that year. $\mathrm{F}(\mathrm{)})$ is the cumulative distribution function of the logistic distribution.

MISS is the magnitude of missing earnings target. The earnings target chosen for focus is the number from analysts' earnings forecast (McAnally, et. al. 2008). Thus MISS is measured as the absolute value of the difference between diluted EPS (Compustat \#57) and the last analyst's median forecast number before earnings announcement (I/B/E/S MEDEST), deflated by stock price per share (Compustat \#199). In addition, earnings volatility is measured as VOLATILE - the standard deviation of deflated earnings within the five years preceding the skipped year in which deflated earnings is considered to be earnings before extraordinary items (Compustat \#123) over the end-of-year total assets (Compustat \#6). Furthermore, firms with earnings where the current year is below the previous year are considered to be the years with bad news. With deflated earnings defined above, the magnitude of the bad news $(B A D)$ is measured as the difference between the current year's deflated earnings and the previous year's deflated earnings. The smaller the variable $B A D$, the worse the expected news. Lastly, a control variable is included for firm size. The control variable is measured as the natural logarithm of market value of equity at the end of the event year.

Financial data were gathered from the CRSP/COMPUSTAT Merged database. Analyst forecast data were collected from I/B/E/S database. As mentioned above, management earnings forecast (annual or quarterly) data were taken from the First Call Company Issued Guidance database.

The initial number of skipped firm-years is 1,168. After a check with newswires, the number of actual skipped firm-years is down to 1,085 . Requiring the availability of financial and analyst forecast data, the number of sample firm-years engaging in skipped years is further reduced to 690. On the other hand, after requesting the availability of financial and analyst forecast data, the 11,948 regular forecasting control firm-years were reduced to 3,197 .

\section{TEST RESULTS}

Table 2 reports the univariate statistics of the variables by skipped firm-years and regular forecasting firmyears. The Wilcoxon tests show that in contrast to regular forecasting firm-years, the firm that skips a year of forecast has missed analysts' earnings forecast more dramatically in the previous year ( $\mathrm{Z}=-6.43$ for MISS). It also shows more volatile earnings in the previous five years $(\mathrm{Z}=-4.25$ for VOLATILE). Furthermore, the firm that skips earnings forecasts tends to be a smaller firm $(\mathrm{Z}=7.88$ for $S I Z E)$ with lower net income $(\mathrm{Z}=8.92$ for $N I)$. 
Table 2: Descriptive Statistics

\begin{tabular}{|l|c|c|c|c|c|c|c|c|}
\hline & \multicolumn{3}{|c|}{ Skipped Firm Years } & \multicolumn{2}{c|}{ Regular Forecasting Firm-Years } & \multicolumn{2}{c|}{ Between-Group } \\
\hline & Obs No. & Mean & Median & Obs No. & Mean & Median & t-Test & Wilcoxon \\
\hline MISS & 690 & 0.1595 & 0.0145 & 3197 & 0.0337 & 0.0082 & $-2.82^{*}$ & $-6.43^{*}$ \\
\hline VOLATILE & 690 & 0.0731 & 0.0297 & 3197 & 0.0516 & 0.0232 & $-3.75^{*}$ & $-4.25^{*}$ \\
\hline BAD & 690 & 0.0057 & -0.0009 & 3197 & -0.0100 & -0.0005 & $-2.14^{*}$ & 0.22 \\
\hline SIZE & 690 & 4827.046 & 651.708 & 3197 & 7716.603 & 1214.066 & $2.56^{*}$ & $7.88^{*}$ \\
\hline NI & 690 & 187.1526 & 17.7965 & 3197 & 344.5094 & 51.6920 & $2.65^{*}$ & $8.92^{*}$ \\
\hline
\end{tabular}

*Significant at the 0.05 level (two-tailed)

MISS = the absolute value of the difference between diluted EPS (Compustat \#57) and the last analyst's median

earnings forecast (I/B/E/S medest), deflated by stock price per share (Compustat \#199), in year t-1.

VOLATILE = standard deviation of five years of deflated earnings preceding the "skipped" year (year $t$ ), where deflated earnings is earnings before extraordinary items (Compustat \#123) deflated by the end-of-year total assets (Compustat \#6).

$\mathrm{BAD} \quad=$ the difference between deflated earnings in year $\mathrm{t}$ and year $\mathrm{t}-1$, where deflated earnings is defined as earnings before extraordinary items (Compustat \#123) deflated by the end-of-year total assets (Compustat \#6).

SIZE = market value of equity, which is the product of common shares outstanding (Compustat \#25) and fiscal year-end close price per share (Compustat \#199).

NI $\quad=$ net income (loss) (Compustat \#172).

Table 3 presents the estimation results from the logit model. The model is estimated with two different groups of firms that skip earnings estimates. The first estimation (1) uses 690 annual forecasting skipped firm-years and 3,197 regular forecasting firm-years. Following that, 606 (out of 690) firms not only skipped their annual earnings forecasts but also their quarterly forecasts. Therefore, the second estimation (2) uses 606 annual and quarterly forecasting skipped firm-years and 3,197 regular forecasting firm-years.

Table 3: Determinants Of The Decision To Skip A Year Of Forecast

\begin{tabular}{|c|c|c|}
\hline & $\begin{array}{l}\text { Estimation (1) } \\
\end{array}$ & $\begin{array}{rr}\text { Estimation (2) } \\
\end{array}$ \\
\hline & $\begin{array}{c}\text { Annual Forecast Skipped Firm-Years versus } \\
\text { Regular Forecasting Firm-Years }\end{array}$ & $\begin{array}{l}\text { Annual and Quarterly Forecast Skipped Firm- } \\
\text { Years versus Regular Forecasting Firm-Years }\end{array}$ \\
\hline Intercept & $\begin{array}{c}0.3489 \\
(0.00) \\
\end{array}$ & $\begin{array}{c}0.3252 \\
(0.00) \\
\end{array}$ \\
\hline MISS & $\begin{array}{l}0.0122 \\
(0.03)\end{array}$ & $\begin{array}{c}0.0126 \\
(0.02)\end{array}$ \\
\hline VOLATILE & $\begin{array}{c}0.0828 \\
(0.08)\end{array}$ & $\begin{array}{c}0.0871 \\
(0.06)\end{array}$ \\
\hline $\mathrm{BAD}$ & $\begin{array}{c}0.0591 \\
(0.11)\end{array}$ & $\begin{array}{l}0.0463 \\
(0.20)\end{array}$ \\
\hline LSIZE & $\begin{array}{c}-0.0249 \\
(0.00) \\
\end{array}$ & $\begin{array}{c}-0.0241 \\
(0.00)\end{array}$ \\
\hline Pseudo- $\mathrm{R}^{2}$ & $2.14 \%$ & $2.45 \%$ \\
\hline
\end{tabular}

Dependent variables $=1$ if the firm skips a year of forecast and $=0$ for a firm who has consistently forecasted its annual earnings. Estimation 1 includes the firm-years that have been identified as skipped firm-years for annual earnings, with or without quarterly earnings forecast. On the other hand, Estimation 2 includes only those firm-years that have skipped both annual and quarterly earnings forecast. p-values are reported in parentheses. Independent variables are defined as follows:

MISS = the absolute value of the difference between diluted EPS (Compustat \#57) and the last analyst's median earnings forecast (I/B/E/S medest), deflated by stock price per share (Compustat \#199), in year t-1.

VOLATILE = standard deviation of five years of deflated earnings preceding the "skipped" year (year $t$ ), where deflated earnings is earnings before extraordinary items (Compustat \#123) deflated by the end-of-year total assets (Compustat \#6).

$\mathrm{BAD}=$ the difference between deflated earnings in year $\mathrm{t}$ and year $\mathrm{t}-1$, where deflated earnings is earnings before extraordinary items (Compustat \#123) deflated by the end-of-year total assets (Compustat \#6).

LSIZE = the natural logarithm of market value of equity, which is the product of common shares outstanding (Compustat \#25) and fiscal year-end close price per share (Compustat \#199). 
The result of the first estimation (1) shows that the likelihood of skipping a year of forecast is significantly higher for firms that have performed very differently from analysts' consensus (coefficient on MISS $=0.0122$, zstatistic $=4.53$ ), even after accounting for firm size. Further, a firm is more likely to skip a year of annual forecast when it has a record of volatile earnings in the previous five years (coefficient on VOLATILE $=0.0828$, z-statistic $=$ 3.04). The results are even more evident for the group that skips annual and quarterly earnings forecasts in the same year (coefficient on MISS $=0.0126$, z-statistic $=5.30$; coefficient on VOLATILE $=0.0871$, z-statistics $=3.63$ ).

\section{CONCLUSION}

The study aims at examining whether corporate disclosure policy is "sticky" and, if so, why. Focusing on management annual earnings forecasts, 1,085 earnings forecast year gaps, in which a firm skips a year or more, were identified, along with the reasons for this behavior. Evidence indicates that firms that miss earnings targets (set by analysts) by a large margin are more likely to skip a year of earnings forecast. The results also suggest that earnings volatility in the previous five years could play a role. The findings, however, do not show that incoming bad news necessarily acts as a determinant. In sum, evidence shows that a firm may not stick to its normal earnings forecast policy in these circumstances. Missing an earnings target from the previous year and experiencing more volatile earnings may cause a firm to skip a year or more of earnings forecasts.

\section{ACKNOWLEDGEMENT}

Thanks are due to all participants at the 2010 AAA Western Regional Meeting and the 2010 AAA annual conference. Also acknowledged is financial support from California State University, East Bay and from the College of Business and Economics at California State University, East Bay.

\section{AUTHOR INFORMATION}

Dr. Jing-Wen Yang received the Ph.D. degrees in Accounting from the University of Maryland, College Park, U.S.A. She is currently an assistant professor at College of Business and Economics at California State University East Bay. Her research interests are in voluntary disclosure behavior, competition and accounting education. E-mail: jingwen.yang@csueastbay.edu

\section{REFERENCES}

1. Anilowski, C., Feng, M., Skinner, D. (2007). Does earnings guidance affect market returns? The nature and information content of aggregate earnings guidance. Journal of Accounting Economics, 44(1-2): 36-63.

2. Baginski, S. P., Hassell, J. M. (1997). Determinants of management forecast precision. The Accounting Review, 72(2): 303-312.

3. Bartov, E., Givoly, D., Hayn, C. (2002) The rewards to meeting or beating earnings expectations. Journal of Accounting and Economics, 33(2): 173-204.

4. Bushee, B. J., Matsumoto, D. A., Miller, G. S. (2003). Open versus closed conference calls: the determinants and effects of broadening access to disclosure. Journal of Accounting and Economics, 34(1-3): 149-180.

5. Chen, S., Matsumoto, D., Rajgopal, S. (2011). Is silence golden? An empirical analysis of firms that stop giving quarterly earnings guidance. Journal of Accounting and Economics, 51(1-2): 134-150.

6. Coller, M., Yohn, T. L. (1997). Management forecasts and information asymmetry: an examination of bidask spreads. Journal of Accounting Research, 35 (2): 181-191.

7. Dye, R. A. (1985). Disclosure of nonproprietary information. Journal of Accounting Research, 23(1): 123145.

8. Fama, E., French, K. (1997). Industry costs of equity. Journal of Financial Economics, 42(2): 153-193.

9. Field, L., Lowry, M., Shu, S. (2005). Does disclosure deter or trigger litigation? Journal of Accounting and Economics 39(3): 487-507.

10. Graham, J. R., Harvey, C. R., Rajgopal, S. (2005). The Economic implications of corporate financial reporting. Journal of Accounting and Economics, 40(1-3): 3-73. 
11. Houston, J. F., Lev, B., Tucker, J. W. (2010). To guide or not to guide? Causes and consequences of stopping quarterly earnings guidance. Contemporary Accounting Research, 27(1): 143-185.

12. Jung, W.-O., Kwon, Y. K. (1988). Disclosure when the market is unsure of information endowment of managers. Journal of Accounting Research, 26(1): 146-153.

13. McAnally, M. L., Srivastava, A., Weaver, C. D. (2008). Executive stock options, missed earnings targets, and earnings management. The Accounting Review, 83(1): 185-216.

14. Miller, G. S. (2002). Earnings performance and discretionary disclosure. Journal of Accounting Research, 40(1): 173-204.

15. Pownall, G., Wasley C., Waymire, G. (1993). The Stock price effects of alternative types of management earnings forecasts. The Accounting Review, 68(4): 896-912.

16. Skinner, D., Sloan, R. (2002). Earnings surprises, growth expectations, and stock returns or don't let an earnings torpedo sink your portfolio. Review of Accounting Studies, 7(2-3): 289-312.

17. Skinner, D. (2003). Should firms disclose everything to everybody? A discussion of "open vs. closed conference calls: the determinants and effects of broadening access to disclosure. Journal of Accounting and Economics, 34(1-3): 181-187.

18. Verrecchia, R. E. (1983). Discretionary disclosure. Journal of Accounting and Economics, 5: 179-194.

19. Waymire, G. (1985). Earnings volatility and voluntary management forecast disclosure. Journal of Accounting Research, 23(1): 268-295. 


\section{NOTES}

